\title{
Monoclonal Antibody 81C6
}

National Cancer Institute

\section{Source}

National Cancer Institute. Monoclonal Antibody 81C6. NCI Thesaurus. Code C1958.

A murine IgG2 monoclonal antibody (MoAb) 81C6 raised ag ainst the extracellular matrix antigen tenascin (hexabrachion), up-regulated in gliomas and other cancers. Conjug ated MoAb 81C6 may be used in diagnosis or treatment of cancers that over-express tenascin. 